\title{
A simplified immunoprecipitation method for quantitatively measuring antibody responses in clinical sera samples by using mammalian-produced Renilla luciferase-antigen fusion proteins
} Peter D Burbelo*, Radoslav Goldman and Thomas L Mattson

Address: Lombardi Comprehensive Cancer Center, Department of Oncology, Georgetown University Medical Center, Washington, D.C. 20057

Email: Peter D Burbelo* - burbelpd@georgetown.edu; Radoslav Goldman - rg26@georgetown.edu;

Thomas L Mattson - tommattson@yahoo.com

* Corresponding author

Published: 18 August 2005

BMC Biotechnology 2005, 5:22 doi:10.1 186/1472-6750-5-22
Received: 03 March 2005

Accepted: 18 August 2005

This article is available from: http://www.biomedcentral.com/I472-6750/5/22

(C) 2005 Burbelo et al; licensee BioMed Central Ltd.

This is an Open Access article distributed under the terms of the Creative Commons Attribution License (http://creativecommons.org/licenses/by/2.0), which permits unrestricted use, distribution, and reproduction in any medium, provided the original work is properly cited.

\begin{abstract}
Background: Assays detecting human antigen-specific antibodies are medically useful. However, the usefulness of existing simple immunoassay formats is limited by technical considerations such as sera antibodies to contaminants in insufficiently pure antigen, a problem likely exacerbated when antigen panels are screened to obtain clinically useful data.
\end{abstract}

Results: We developed a novel and simple immunoprecipitation technology for identifying clinical sera containing antigen-specific antibodies and for generating quantitative antibody response profiles. This method is based on fusing protein antigens to an enzyme reporter, Renilla luciferase (Ruc), and expressing these fusions in mammalian cells, where mammalian-specific posttranslational modifications can be added. After mixing crude extracts, sera and protein A/G beads together and incubating, during which the Ruc-antigen fusion become immobilized on the A/G beads, antigen-specific antibody is quantitated by washing the beads and adding coelenterazine substrate and measuring light production.

We have characterized this technology with sera from patients having three different types of cancers. We show that $20-85 \%$ of these sera contain significant titers of antibodies against at least one of five frequently mutated and/or overexpressed tumor-associated proteins. Five of six colon cancer sera tested gave responses that were statistically significantly greater than the average plus three standard deviations of 10 control sera. The results of competition experiments, preincubating positive sera with unmodified $E$. coli-produced antigens, varied dramatically.

Conclusion: This technology has several advantages over current quantitative immunoassays including its relative simplicity, its avoidance of problems associated with $E$. coli-produced antigens and its use of antigens that can carry mammalian or disease-specific post-translational modifications. This assay should be generally useful for analyzing sera for antibodies recognizing any protein or its post-translational modifications.

\section{Background}

Although it is clear that a normal host immune system rec- ognizes and responds to tumors, we understand very little about these complex tumor-host interactions. For 
example, it is not clear why tumor-associated proteins elicit humoral responses, although it is often speculated that such proteins can become antigenic when they are overexpressed or represent an unusual or modified form of a protein (e.g. altered spliced form), or are encoded by mutant genes $[1,2]$. Efforts to identify antibody responses to tumor antigens are motivated primarily by their diagnostic potential. Unfortunately, the immunoassay formats available to most laboratories are less than ideal.

Most immunoassays use bacterial-expressed proteins for detecting antigen-specific antibodies in human sera [2]. However, since such antigens do not carry post-translational modifications or may fold incorrectly, some immunoassays employ antigens produced in either yeast or insect cells. While these antigens may fold correctly and carry post-translational modifications, they will not carry either mammalian- or disease-specific posttranslational modifications. Tests employing bacterial-produced proteins can produce high backgrounds because it is difficult to completely eliminate or block serum antibodies reactive with trace amounts of bacterial contaminants present in most antigen preparations, even in pharmaceutical grade preparations [3]. Therefore to overcome the biological limitations and technical problems associated with bacterially and non-mammalian-produced antigens, we have developed a simple immunoassay that combines conventional immunoprecipitation techniques with a novel approach for the production of tumor antigens. The tumor antigens are fused to an enzymatic reporter, Ruc, and produced in mammalian cell cultures, where mammalian-specific post-translational modifications can be added. This technology is based on our previously published studies showing that a Ruc fusion with a human protein retain the biological activities of both the reporter and the human protein and can be used to detect weak protein-protein interactions [4]. In the present application, we utilized such fusions to detect protein-antibody interactions.

Our immediate interest in this technology is that we believe it can be used to systematically test the hypothesis that, in sporadic cancers, mutant or overexpressed tumorassociated proteins frequently induce humoral responses. While variations of this hypothesis have be proposed, it has not been vigorously tested for mainly historical and technological reasons. Until recently, only a few frequently mutated tumor-associated proteins were known [5]. For example, in sporadic breast and colon cancers, mutations in only a few proteins, p53 and SMAD4 or p53, k-Ras and APC, respectively, had been identified prior to 2001. Recent molecular genetic studies have greatly increased the number of genes known to be mutant in different types of sporadic cancers. For example, in colon cancers over 15 different genes are known to be frequently mutated [6-10], although individual patient tumors are highly heterogeneous in their mutant gene spectrum. In light of the fact that accurate classification of patient tumors into well-defined subtypes by gene expression profiling requires a panel of genes, each of which may be specifically up- or down-regulated in only a small percentage of tumors [11-15], we hypothesize that monitoring humoral immune responses to a panel of frequently mutated and/or overexpressed tumor-associated proteins in cancer patient sera can be used in an analogous manner, but with the added advantage of not requiring tumor tissue. In addition, existing data suggests that cancer patients' antibody responses to these mutant proteins are generally not limited to the mutated region of the protein. For example, colon cancer patient sera containing anti-Ras antibodies were equally reactive with either wild type or mutant K-Ras recombinant proteins [16]. Epitope mapping experiments showed that these sera always reacted with the C-terminus of K-Ras, although the mutated amino acid is almost always at the N-terminus of Ras. Similar results studying antibody responses to p53 were obtained with sera from patients with breast, colorectal and lung cancer [17]. While p53 mutations are in the central region, the majority of immunodominant epitopes are in the $\mathrm{N}$ - and/or C-termini of p53 [18,19]. For both mutant CDX2 in colon cancer, and mutant B-Raf in melanoma, patient antibodies react with both the wild type protein and mutant epitopes [20,21]. Here we describe a simple practical quantitative immunoprecipitation assay that has a number of practical advantages including that it is inexpensive, easy-to-perform and can be used for detecting antigen-specific antibodies in clinical sera samples. The proteins used here, as antigens are frequently mutated or overexpressed in the types of tumors carried by the patients whose sera are used to demonstrate the usefulness of this new immunoassay format.

\section{Results and discussion \\ Description of the immunoprecipitation assay}

We used Ruc-tagged proteins to develop an immunoprecipitation assay that can quantitatively measure serum antibody reactivity with protein antigens. Briefly, crude extract containing the Ruc-antigen fusions, sera and protein $\mathrm{A} / \mathrm{G}$ beads are mixed together and incubated, during which the antigen fusions become immobilized; antigenspecific antibody is then quantitated by washing the beads and adding the colenterazine substrate. In these assays the amount of light produced is proportional to the amount of soluble fusion protein captured, directly or indirectly by the antibody-bound beads. It should be noted that the binding capacity of the protein A/G beads (Pierce Biochemical) used to capture either purified monoclonal antibodies or immunoglobulins from crude human or animal antisera is quite high ( $24 \mu \mathrm{g}$ of immunoglobulins/ $\mu$ l of packed beads). 


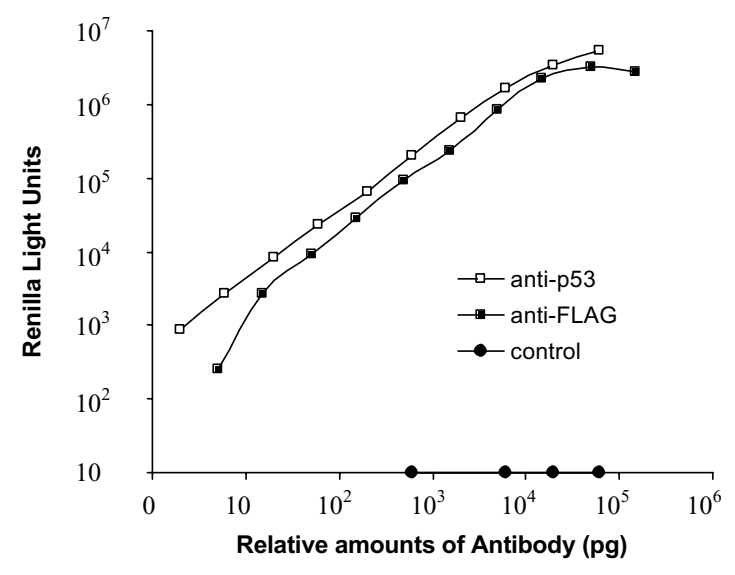

\section{Figure I}

Immunoprecipitation experiments with commercial antibodies. Various amounts of anti-FLAG monoclonal, anti-p53 polyclonal or control (anti-WASP) polyclonal antibodies were mixed with $5 \mu$ l of a Cos I extract containing Ruc-p53 for I h in the presence of protein $A / G$ beads, processed and light units measured. The data shown is from one of three independent experiments giving similar results.

\section{The immunoprecipitation assay shows a linear range of detection with commercial antibodies}

To illustrate this technology we generated Ruc fusion protein constructs for p53, K-Ras, c-Myc, $\beta$-catenin and Smad4 by fusing cDNAs encoding these proteins (in frame) to DNA encoding the C-terminus of Ruc in a mammalian expression vector, pREN2, which also encodes a FLAG epitope tag at the N-terminus of Ruc. Transfections into Cos 1 cells of these different constructs yielded crude extracts with $3-10 \times 10^{8}$ Ruc light units per $100 \mathrm{~mm}^{2}$ plate. We developed a standard assay format by using a commercial anti-FLAG monoclonal antibody and Cos1 cell extracts containing Ruc-p53. When crude extract, antisera and protein A/G beads were incubated together in a single tube, the amount of immunoprecipitated Rucp53 was directly proportional to the amount of anti-FLAG antibody over a 1000-fold range of concentrations, with a lower limit of detection of less than 5 picrograms (Figure 1). A commercial anti-p53 polyclonal antibody had a similar capture capacity as reflected by a similar doseresponse curve, whereas a commercial polyclonal antibody against an unrelated antigen was unable to immunoprecipitate Ruc-p53 (Figure 1). Experiments using commercial polyclonal antibodies for serine-15 phosphorylated p53 and acetylated p53 (lysine-373 and lysine382) also immunoprecipitated significant amounts of
Ruc-p53 (data not shown). Since the ability of these modification-specific antibodies to immunoprecipitated Rucp53 was not competed by bacterially produced recombinant p53 protein (data not shown), this fusion protein appears to contain at least two types of post-translational modifications.

\section{Human cancer patient sera contain antigen-specific antibodies}

Since commercial antibodies can immunoprecipitate Rucantigen fusions from crude Cos1 extracts, we tested whether our simple assay format could also detect antigen-specific antibodies in clinical sera samples. Our motive for developing this technique was to have an improved method for detecting cancer patient antibody responses to tumor-associated proteins. Thus, we initially tested it with a small number of clinical sera samples taken from patients having three types of cancers, breast, colon and head and neck. In order to maximize our chances of detecting positive responses with these clinical sera samples we chose to use p53 and four other tumorassociated proteins (K-Ras, c-Myc, $\beta$-catenin and Smad4) that are either frequently mutated and/or overexpressed in various tumors. Wild type proteins were used as antigens because several studies show that cancer patient sera humoral immune responses are not restricted to or even preferential for the epitopes that usually contain the altered amino acids [16,18-21]. Cos 1 extracts containing Ruc-antigen fusions were used to test a total of 36 sera, 10 controls and 26 cancer patients (Table 1). Negative and positive controls consisting of protein A/G beads alone and $0.1 \mu \mathrm{g}$ of anti-FLAG monoclonal antibody with protein A/G beads, respectively, were used for each experiment. As expected, all sera had low reactivity with the non-specific binding control protein, Ruc-alone (Table 1). The positive control, anti-FLAG antibody, immunoprecipitated significant amounts of each of the Ruc-antigen fusions. However, the fraction of the total Ruc activity that could be captured varied amongst the different Ruc-antigen fusions, possibly reflecting reduced accessibility to the N-terminal FLAG epitope in some constructs (data not shown). At least one cancer patient sera had statistically significant antibody responses to each of the five Ruc fusions, where significance is defined as a response greater than the average plus three standard deviations of the 10 control sera (Table 1). Two of 10 head and neck, five of 10 breast, five of six colon cancer sera, but none of 10 healthy control sera gave positive responses. Six of the 12 positive tests were clustered in the six colon cancer patient sera and two antigens, p53 and K-Ras (Table 1). The significance of the relative response rates between different cancer-type sera cannot be calculated because the sample sizes are small and because no effort was made to match the control and patient sera by any criteria. Similarly, we cannot conclude that either K-Ras and/or p53 may be more 
A.

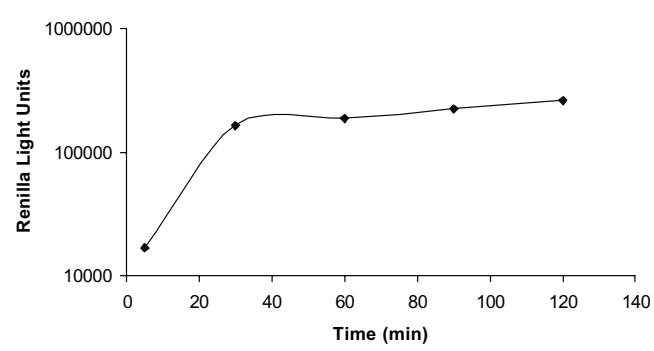

B.

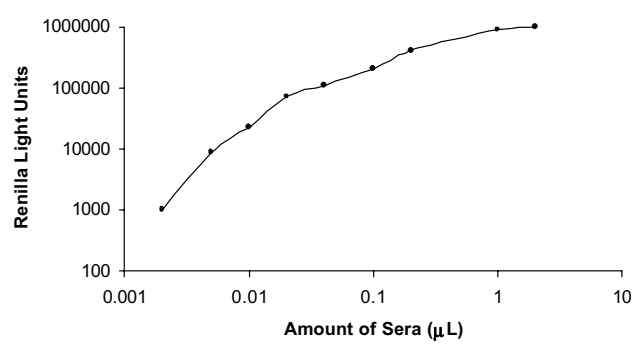

Figure 2

The immunoprecipitation assay with Ruc-p53 and a clinical serum sample. A: The immunoprecipitation activity is proportional to incubation time. Tubes containing identical amounts of Ruc-p53 fusion protein extract $(5 \mu \mathrm{l})$, patient 34 sera $(I \mu l)$ and protein $A / G$ beads were incubated for 5,30 , 60,90 and 120 min and processed for luciferase activity. B: Immunoprecipitation activity with various amounts of total crude patient 34 sera. Different amounts of patient sera ( 0.002 to $2 \mu \mathrm{l})$ were mixed with $5 \mu \mathrm{l}$ of the Ruc-p53 fusion protein extract and incubated for $I$ hour in the presence of protein A/G beads, processed and light units measured. The data shown is from one of three independent experiments giving similar results.

antigenic in colon cancers than either $\beta$-catenin or c-Myc. Interestingly, the only multiple sample from any of the patients, head and neck samples 11 and 12, are sequential samples of which only the more recent sample showed significant levels of anti-p53 antibodies. Since the proteins used to test for antibodies in these 26 cancer patient sera are often mutated and/or overexpressed in the three types of cancer, our results are consistent with studies indicating that these categories of proteins are often antigenic in cancer patients [2]. Our results with colon cancer patient sera also support proposals that humoral immune responses to panels of tumor-associated antigens may be clinically useful when single antibody responses are not informative $[22,23]$. In any case, the detection of cancer sera from head and neck (20\% sensitivity and $100 \%$ specificity), breast (40\% sensitivity and $100 \%$ specificity), and colon ( $86 \%$ sensitivity and $100 \%$ specificity) obtained using a panel of five antigens are encouraging, given that our assay is not yet optimized and the sample sizes are small.

To determine whether patient antibody responses behave in the same linear manner as the commercial antibodies, we used the most reactive combination of patient sera and fusion antigen in our small sample set, colon cancer sera 34 and the Ruc-p53 fusion. Although the amount of Rucp53 captured by this serum is roughly linear with incubation time in the presence of protein $\mathrm{A} / \mathrm{G}$ beads, reaching a plateau by $30-60$ minutes (Figure 2A), the relative amount of immunoprecipitated Ruc-p53 was not completely linear with increasing amounts of sera (Figure 2B). Since the two commercial antibodies used in Figure 1 are highly purified, the non-linear dose-response curve of the clinical sera sample could be due to interfering agents such as anti-p53-specific IgA and IgM antibodies that recognize epitopes also recognized by IgG's but which bind poorly to protein A/G beads [24]. We are exploring modifications of the assay format in order to produce a more linear dose-response curve with clinical sera samples, which if found, would facilitate assay standardization and might increase sensitivity (note that 1-2 of the colon cancer responses to one of the antigens tested, $\beta$-catenin- $\Delta 1$, are barely below the cut-off value used to judge statistical significance). If the presumed interfering agents also affected ELISA tests, ELISA tests may significantly underestimate positive antibody responses and antibody titers unless the sera are sufficiently diluted.

\section{Competition experiments with unmodified proteins}

While human humoral immune responses to post-translational modifications are often ignored and/or undetectable with existing technologies, recent studies demonstrate that disease-related antibody responses can occur to post-translational protein modifications [25]. In at least one case, rheumatoid arthritis, antibody responses to a post-translational modification, citrullination, is now being intensely investigated as a potentially reliable disease indicator $[26,27]$. In light of these observations, we asked whether each positive sera response seen in Table 1 could include antibodies that were directed toward posttranslational modifications by doing competition experiments with unmodified $E$. coli-produced antigens. These competition experiments (Table 2) show that $0-$ $100 \%$ of the immunoprecipitated Ruc-antigen fusions were blocked by preincubating sera with $5 \mu \mathrm{g}$ of the corresponding E. coli-produced antigens fused to maltose binding protein (MBP). These differences occur even between sera containing antibodies that recognize the same antigen (e.g. p53 or K-Ras), proteins known to contain post-translational modifications. These differences could mean that some tumors tend to produce 
Table I: Immunoprecipitation capacity of I $\mu$ l of human sera for Ruc-tumor antigen fusion proteins ${ }^{a}$

\begin{tabular}{|c|c|c|c|c|c|c|c|}
\hline & & Ruc & p53 & K-Ras & Smad4 & $\beta-C A T-\Delta I$ & c-Myc \\
\hline \multirow[t]{10}{*}{ Controls } & 1 & 194 & 19,319 & 480 & 10,582 & 269 & 4,752 \\
\hline & 2 & 9 & 9,830 & 1,064 & 3,575 & 835 & 2,913 \\
\hline & 3 & 8 & 5,236 & 445 & 1,773 & 211 & 2,006 \\
\hline & 4 & 38 & 3,187 & 477 & 1,919 & 530 & $|, 83|$ \\
\hline & 5 & 14 & 11,908 & 795 & 6,884 & 161 & 3,346 \\
\hline & 6 & 31 & 5,390 & 823 & $\mathrm{I}, 724$ & 235 & 2,050 \\
\hline & 7 & 76 & 22,526 & 1,909 & 6,996 & 259 & 11,816 \\
\hline & 8 & 29 & 15,338 & 943 & 8,043 & 445 & 3,475 \\
\hline & 9 & 10 & 12,282 & 1,162 & 19,380 & 215 & 3,623 \\
\hline & 10 & 9 & 11,130 & 1,109 & 4,429 & 501 & 5,060 \\
\hline $\bar{x}+3 S D^{b}$ & & 214 & 30,234 & 2,237 & 22,788 & 997 & 12,874 \\
\hline \multirow{10}{*}{ Head and Neck } & 11 & 0 & 10,904 & 508 & 2,721 & 196 & 2,193 \\
\hline & 12 & 0 & $31,593 c$ & 738 & 4,822 & 465 & 3,801 \\
\hline & 13 & 0 & 12,367 & 840 & 1,868 & 673 & 4,407 \\
\hline & 14 & 13 & 14,705 & 1,012 & 5,666 & 195 & I,837 \\
\hline & 15 & 33 & $31,733^{c}$ & 1,189 & 5,264 & 552 & 4,107 \\
\hline & 16 & 121 & 4,828 & 621 & 980 & 279 & 1,974 \\
\hline & 17 & 0 & 8,517 & 1,160 & 8,396 & 336 & 2,958 \\
\hline & 18 & 0 & 19,240 & 1,283 & 9,485 & 327 & $|, 8| 4$ \\
\hline & 19 & 0 & 11,224 & 1,517 & 4,454 & 410 & 4,370 \\
\hline & 20 & 28 & 7,322 & 554 & 2,261 & 723 & 2,343 \\
\hline \multirow[t]{10}{*}{ Breast } & 21 & 44 & $|3,2| \mid$ & 960 & 10,219 & 308 & 5,988 \\
\hline & 22 & 10 & 18,814 & 696 & $42,970 c$ & 302 & 5,450 \\
\hline & 23 & 38 & 14,598 & 608 & 8,484 & 339 & 4,336 \\
\hline & 24 & 77 & 11,587 & 1,655 & 17,297 & $2363^{c}$ & 3,431 \\
\hline & 25 & 17 & 19,954 & 532 & 10,184 & 772 & $15,650 \mathrm{c}$ \\
\hline & 26 & 25 & 9,538 & 195 & 5,962 & 300 & 1,646 \\
\hline & 27 & 10 & 7,815 & $2,56 I^{c}$ & 20,628 & 426 & 3,524 \\
\hline & 28 & 21 & 15,607 & 308 & 7,380 & 284 & 1,579 \\
\hline & 29 & 0 & 18,058 & 160 & 6,790 & 304 & 2,333 \\
\hline & 30 & $245^{c}$ & 25,479 & 1,919 & 9,727 & 495 & 3,787 \\
\hline \multirow[t]{6}{*}{ Colon } & 31 & 4 & 6,656 & 1,204 & 3,252 & 267 & 1,763 \\
\hline & 32 & 40 & 20,928 & $4,293^{c}$ & 5,567 & 962 & 6,143 \\
\hline & 33 & 42 & $34,703^{c}$ & $\mathrm{I}, 472$ & 10,830 & 716 & 4,906 \\
\hline & 34 & 51 & $300,943^{c}$ & $6,439 c$ & 2,610 & 992 & 3,789 \\
\hline & 35 & 35 & 5,670 & $3,306 c$ & 3,860 & 477 & I,772 \\
\hline & 36 & 44 & 6,516 & 695 & $37,344^{c}$ & 371 & 2,395 \\
\hline
\end{tabular}

aSera, FLAG-Ruc-fusion extracts, protein A/G beads and buffer were mixed together, incubated for 60 minutes and processed. The data, light units, is the average of two experiments and is corrected for background (beads plus extract, but no sera). The standard deviation for each value is also available (see Additional file I).

bValues of the averages of the 10 control sera plus 3 standard deviations.

cNumbers in bold are statistically significant: greater than the average plus 3 standard deviations of the 10 control sera.

proteins having more post-translational modifications or that some cancer patient's immune system tend to produce significantly more antibodies that recognize posttranslational modifications. However, this data does not exclude the possibility that some or all of each positive antibody response detected is not even specific for the antigen listed, since the apparent anti-p53 or anti-K-Ras antibodies could be directed toward proteins that are in complexes with these tumor antigens. If the tumor antigens in these complexes were easily replaced by the MBP fusions, one would see higher competition values than if they were inefficiently replaced. Quantitative evaluation of different competition results requires, at a minimum, equal amount of reactive antibodies in each sera, a condition unlikely to be satisfied here, especially for the p53reactive sera. In addition, when we compared the dose- 
Table 2: Competition of antibody responses by unmodified antigens ${ }^{\mathrm{a}}$

\begin{tabular}{|c|c|c|c|c|c|c|}
\hline Antigen/sera & Control & p53 & K-Ras & Smad4 & $\beta-C A T-\Delta I$ & c-Myc \\
\hline p53/12 & $21 \%$ & $32 \%$ & & & & \\
\hline$p 53 / 15$ & $20 \%$ & $60 \%$ & & & & \\
\hline p53/33 & $7 \%$ & $88 \%$ & & & & \\
\hline p53/34 & $11 \%$ & $72 \%$ & & & & \\
\hline K-Ras/27 & $5 \%$ & & $91 \%$ & & & \\
\hline K-Ras/32 & $25 \%$ & & $82 \%$ & & & \\
\hline K-Ras/34 & $4 \%$ & & $0 \%$ & & & \\
\hline K-Ras/35 & $16 \%$ & & $100 \%$ & & & \\
\hline Smad4/22 & $4 \%$ & & & $92 \%$ & & \\
\hline Smad4/36 & $0 \%$ & & & $93 \%$ & & \\
\hline$\beta$-catenin- $\Delta \mathrm{I} / 24$ & $23 \%$ & & & & $96 \%$ & \\
\hline c-Myc/25 & $0 \%$ & & & & & $22 \%$ \\
\hline
\end{tabular}

aSera $(\mathrm{I} \mu \mathrm{l})$, buffer and $5 \mu \mathrm{g}$ competitor were incubated together for $60 \mathrm{~min}$ before adding the fusion extracts and protein $\mathrm{A} / \mathrm{G}$ beads for an additional 60 minutes and processed. Background light units (beads plus extract but no sera) were subtracted before calculating percent competition. The first column identifies the antigen-sera combination tested. The other columns give the amount of competition obtained for each competitor antigen. All competitors, including the control (SPEC2), are MBP fusion proteins. Values are the averages plus from two independent experiments. The standard deviation for each value is also available (see Additional file 2).

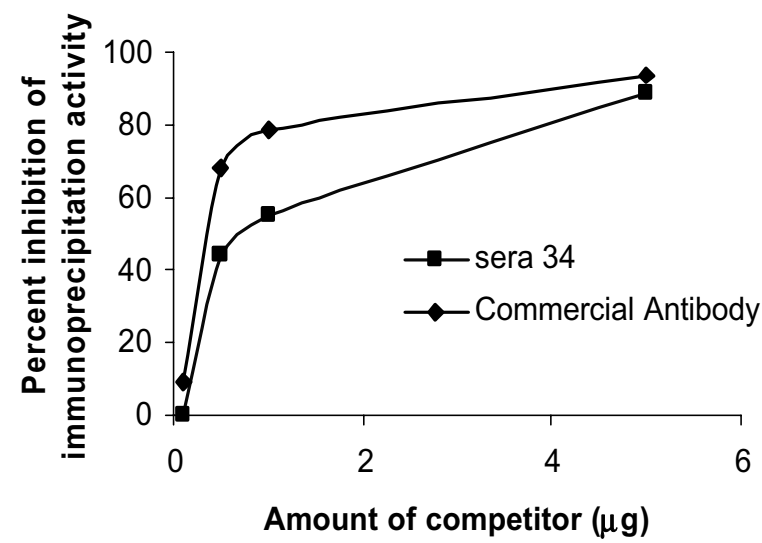

Figure 3

Competition assays blocking Ruc-p53 immunoprecipitation using bacterially-produced antigen. Different amounts of $E$. coli-produced MBP-p53 were incubated with patient sera 34 $(0.5 \mu \mathrm{l})$ or commercial anti-p53 antibody $(25 \mathrm{ng})$ for I h. Protein A/G beads and Ruc-p53 extract were then added and incubated for an additional I $h$, processed and light units measured. The data shown is from one of two independent experiments giving similar results.

response competition curves of sera 34 and the commercial polyclonal anti-p53, adjusted to similar capacities for immunoprecipitating Ruc-p53, we found a greater difference than indicated by the end-point values alone (Figure 3 ). Nevertheless, it is clear that our assay identifies patient sera having qualitatively different humoral immune responses to the same antigen. Additional tools, especially antigens bearing only a single type of modification, will be required to determine whether some or all of the presumed "low affinity" antibodies prefer epitopes bearing post-translational modifications because many such antibodies are likely to cross-react with unmodified epitopes.

We have preliminary observations suggesting that our approach of making antigen-enzyme fusions and producing these fusions in mammalian cells may be superior to conventional ELISA assays for detecting antigen-specific antibody responses in human sera. Specifically, we have tested the six colon cancer patient sera used here in a standard sandwich type ELISA where the antigen were fused to E. coli MBP and immobilized on ELISA plates with a monoclonal anti-MBP antibody. In these ELISA tests only two of the six colon cancer sera gave positive responses with any of the five tumor-associated proteins listed in Table 1 (data not shown). In any case, the immunoprecipitation assay described here offers a practical approach for identifying post-translational modification-specific antibody responses and studying their medical relevance.

\section{Conclusion}

These results demonstrate that a simple quantitative immunoprecipitation assay can identify human clinical sera samples containing disease-related antigen-specific antibodies. Quantitative results were obtained by using easily prepared crude cell extracts containing post-translationally modified antigens fused to a light-producing enzyme reporter. While the immunodetection of antigenenzymes is not new $[28,29]$, by combining a robust reporter, such as Ruc with the production of recombinant 
enzyme-antigen fusions in mammalian cells, we have created a highly sensitive user friendly assay. This assay requires fewer manipulations for reagent preparation and less time than other immunoprecipitation methods including avoiding having to purify and then radiolabel the purified proteins or having to perform additional analysis such as Western blotting after the immunoprecipitations [30]. Producing the target antigens in mammalian cells offers several potential advantages, including having mammalian-specific and/or disease-specific post-translational modifications added to these antigens. Thus, this immunoprecipitation assay provides a simple, accessible, reliable and reproducible tool for investigations aimed at documenting the role of posttranslational modification in disease. Although altered post-translationally modified proteins occur in cancer [31,32], future studies are needed to explore whether there are detectable cancer patient-specific antibodies to post-translationally-modified tumor proteins. The levels and kinds of post-translational modifications on the Rucantigen fusions can be manipulated by exploiting mutant proteins, unique human cell lines (e.g. cell lines overexpressing tyrosine kinases) and various culture conditions. Mammalian-produced antigens have additional advantages over bacterial produced antigens including facilitating the study of antibody responses to very large proteins $(>100 \mathrm{kDa})$ that are difficult or impossible to produce as intact proteins in E. coli. Our assay also avoids false positives caused by variable amounts of anti-E. coli antibodies present in patient sera that react with the minor amounts of E. coli proteins that co-purify with bacterial recombinant proteins; such contaminants are even present in some pharmaceutical-grade recombinant protein preparations [3]. These advantages, along with the possibility of improving the assay format, suggest that it may be worthwhile to use this assay to reevaluate the frequency with which known tumor-associated proteins are detectably antigenic in cancer patients. It is encouraging, although of limited significance, that the frequencies of significant antibody responses for two of the cancers are roughly comparable to reports in the literature. Thus, in colon cancer patients we detected statistically significant antibody responses to Ras and p53 in 50\% and 33\% of the sera, respectively, compared to published reports of 33\% for Ras [16] and 26\% for p53 [33]. In contrast, we did not find any statistically significant antibody responses to p53 in breast cancer sera, which have been reported to occur with $9 \%$ of patient sera [34]. Studies with much larger sample numbers are clearly needed to make statistically useful comparisons between our method and existing methods.

This assay format and high throughput modifications (e.g. magnetic A/G beads in a microtiter plate format) are obviously directly applicable to detecting human sera antibodies specific for any protein antigen of interest and is likely to be useful for non-human sera, such as sera obtained from animal models of disease, as well as for antibodies in other bodily fluids including from ascites and saliva. Variations of this immunoprecipitation assay format might also be useful for studying other types of protein-protein interactions.

\section{Methods \\ Biochemical reagents and antibodies}

Ultralink ${ }^{\mathrm{TM}}$ immobilized protein $\mathrm{A} / \mathrm{G}$ beads were obtained from Pierce Biotechnology Inc. Commercially available antibodies were: mouse monoclonal anti-FLAG ${ }^{\text {тм }}$ M2 from Sigma; rabbit anti-acetylated p53 from Upstate Biochemicals and polyclonal rabbit anti-p53, polyclonal rabbit phosphoserine p53 and polyc lonal anti-WASP from Santa Cruz Biotechnology.

\section{Patient sera}

The breast and colon cancer patient sera were obtained from the University of Wisconsin collection, now kept at Georgetown University Medical Center. Sera samples from head and neck cancer patients and control sera were collected by Dr. Radoslav Goldman at Georgetown University Medical Center (Washington, DC). The sex, age and disease stages of these samples were not examined until after the reactivities for all antigens were measured.

\section{Generation of constructs encoding Ruc fused to tumor- associated antigens}

pREN2, a FLAG-epitope-tagged mammalian expression vector, similar to the previously described pREN1 [4], was used to generate all plasmids encoding Ruc fusions. The tumor antigens are at the C-terminus and a single FLAG tag is at the N-terminus of Ruc. A map of pREN2 is shown in Figure 4. The cloned human cDNA fragments, amplified by PCR specific linker-primer adapters, were obtained from Dr. E. Chang (p53), Dr. R. Lechleider (Smad4), Dr. S. Byers ( $\beta$-catenin), Dr. R. Dickson (c-Myc) and a publicly available cDNA clone (IMAGE ID 6714574) for K-Ras. Full-length coding sequences (excluding the initial methionine) were used for the tumor antigens, with the exception of the $\beta$-catenin, which encodes amino acids 2277 . In every case a stop codon was included after the Cterminal coding sequences of the tumor antigens. The primer adapter sequences used for cloning each antigen are as follows: p53, 5'-GAGGGATCCGAGGAGCCGCA GTCAGAT-3' and 5'-GAGCTCGAGTCAGTCTGAGTCAGGCC-3'; K-Ras, 5'-GAGGGATCCACTGAATATAAACTTGTG-3' and 5'-GAGCTCGAGTTACATAATTACACACTT; Smad4, 5'-GAGGGATCCGACAATATGTCTATTACG-3' and 5'-GAGCTCGAGTCAGTCTAAAGGTTGTGG-3'; $\beta$-catinin- $\Delta$, 5'-GAGGGATCCGCTACTCA AGCTGATTTG-3' and 5'-GAGGTCGACTCAACCAGCTAAACGCACTGC-3'; and c-Myc, 5'-GAGG GATCCCTCAACGTTAGCTTCACC- 


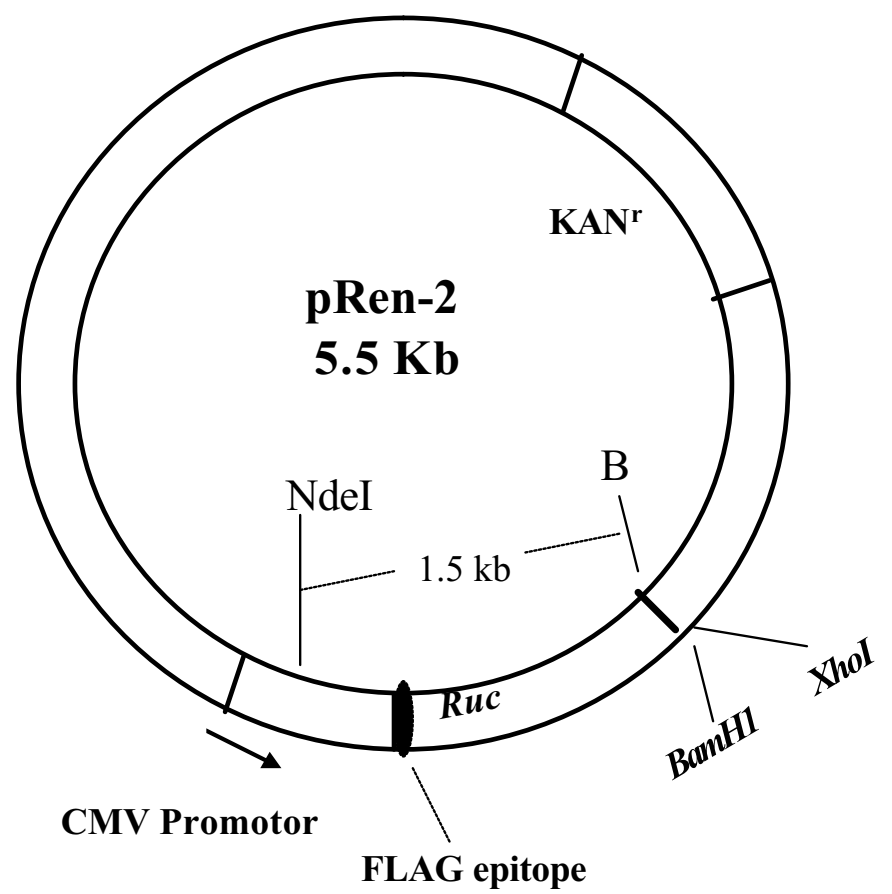

RENILLA luciferase

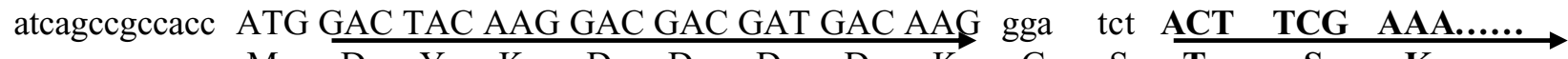

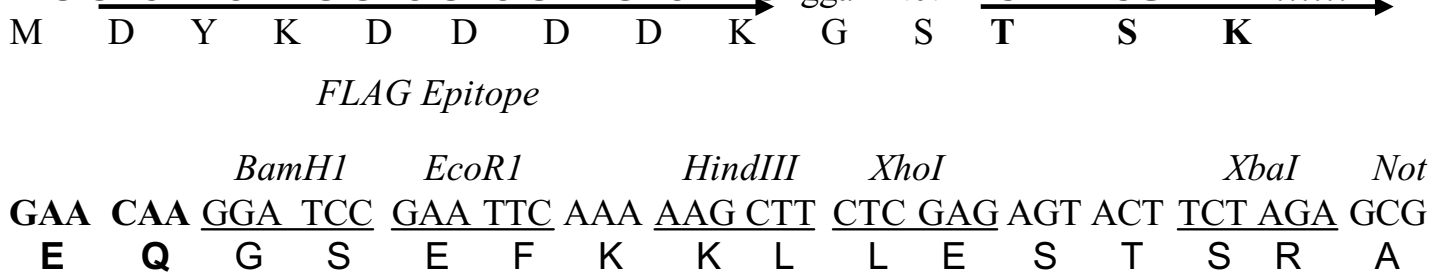

Figure 4

Structure of the pREN2 mammalian expression vector. Features indicated are CMV (cytomegalovirus) promoter, the N-terminal FLAG epitope and Ruc. Sequences for Ruc are in bold. cDNAs for tumor antigens were cloned downstream of Ruc between the BamHI-Xhol sites.

3' and 5'-GAGCTCGAGTTACGCACAAGAGTTCCG-3'. For Ruc alone, a separate construct was prepared containing a stop codon at the end of the luciferase coding sequence in place of the polylinker present in pREN2.

\section{Immunoprecipitation assays with Ruc fusion proteins}

Forty-eight hours after Fugene- 6 transfection, Cos 1 cells in $100 \mathrm{~mm}^{2}$ plates were washed twice with PBS, scraped with $1.0 \mathrm{ml}$ of Buffer A (20 mM Tris, pH 7.5, $150 \mathrm{mM} \mathrm{NaCl}, 5$ $\mathrm{mM} \mathrm{MgCl} 2,1 \%$ Triton X-100) plus 50\% glycerol and protease inhibitors $(10 \mu \mathrm{g} / \mathrm{mL}$ each of leupeptin, aprotinin and pepstatin), sonicated, centrifuged at 13,000 $\times \mathrm{g}$ for 4 min, supernatants collected and used immediately or stored at $-20^{\circ} \mathrm{C}$. Total luciferase activity in $1 \mu \mathrm{l}$ of each crude extract was measured by adding it to $100 \mu$ l of assay buffer and substrate mixture (Renilla Luciferase Reagent Kit, Promega) in a $12 \times 75 \mathrm{~mm}$ glass tube, vortexing and immediately measuring light-forming units with a luminometer (GeneProbe) for $10 \mathrm{sec}$. Lysate prepared from each $100 \mathrm{~mm}^{2}$ plate of transfected Cos 1 cells typically provides enough extract for 60-200 assays. These crude Cos 1 extracts containing these Ruc fusions were stable for at least a few weeks when stored in 50\% glycerol at $-20^{\circ} \mathrm{C}$. 
Immunoprecipitation assays were performed in $100 \mu \mathrm{l}$ volumes containng $6 \mu \mathrm{l}$ of a $30 \%$ suspension of protein $\mathrm{A} /$ $\mathrm{G}$ beads (in PBS), 1-10 $\mu \mathrm{l}$ sera (undiluted or diluted in Buffer A plus $100 \mu \mathrm{g} / \mathrm{ml}$ BSA), sufficient Cos 1 cell extract to generate $1-5$ million light units (usually $5 \mu \mathrm{l}$ to $10 \mu \mathrm{l}$ ) and Buffer $\mathrm{A}$ and incubated at $4{ }^{\circ} \mathrm{C}$ with tumbling for 5120 minutes, washed 4-5 times with $1.2 \mathrm{ml}$ of cold Buffer A and once with $1.0 \mathrm{ml}$ of PBS. After the final wash, the beads, in a volume of about $10 \mu \mathrm{l}$, were added to the Ruc substrate and light units measured as described above. Since the capacity of these protein A/G is $24-32 \mathrm{mg} / \mathrm{ml}$ of packed beads, $2 \mu$ l of packed beads should be sufficient to immobilize most or all of the IgG in $1 \mu \mathrm{l}$ of undiluted sera (assumed to be $10 \mathrm{mg} / \mathrm{ml} \mathrm{IgG).} \mathrm{The} \mathrm{amount} \mathrm{of} \mathrm{IgG} \mathrm{in} 2 \mu \mathrm{l}$ of each sera that actually bound to protein A/G beads was estimated by measuring the amount of bead-bound sera released by a low $\mathrm{pH}$ glycine elution buffer and measured using the BCA Protein Assay kit (Pierce Biotechnology Inc.). The protein values varied from $2.0 \mu \mathrm{g}$ to $7.3 \mu \mathrm{g} / \mu \mathrm{l}$ of patient sera (see Additional file 3).

Competition experiments were performed using MBP fusion proteins. Bacterial expression vectors were constructed by subcloning cDNA fragments into the pMAL-c2 vector (New England Biolabs). Recombinant MBP fusion proteins were produced in bacteria, purified by amyloseagarose affinity and eluted with maltose as described by the manufacturer and stored frozen or in $50 \%$ glycerol at $-20^{\circ} \mathrm{C}$. An MBP fusion containing the SPEC2 cDNA [35] was produced and used as a non-specific inhibitor. The integrity of the proteins was confirmed by SDS-PAGE electrophoresis and protein concentration determined. Diluted patient sera (10 $\mu \mathrm{l}$ used of sera diluted 1:10 in buffer A containing $100 \mu \mathrm{g} / \mathrm{ml} \mathrm{BSA}$ ) were used in the competition experiments described in Table 2, while only $5 \mu \mathrm{l}$ of 1:10 diluted colon patient sera 34 was used in the experiments described in Figure 3.

\section{Authors' contributions}

RG provided the sera samples for the controls and head and neck cancers. TLM produced the recombinant fusion proteins used for the competition experiments and assisted in reducing the concept to practice and manuscript writing. PDB* first conceived of the concept, generated the constructs and performed the immunoprecipitation experiments.

\section{Additional material}

\section{Additional File 1}

Table 1. Mean and standard deviations of sera reactivity

Click here for file

[http://www.biomedcentral.com/content/supplementary/14726750-5-22-S1.pdf]

\section{Additional File 2}

Table 2. Competition of antibody responses by unmodified antigens Click here for file

[http://www.biomedcentral.com/content/supplementary/14726750-5-22-S2.pdf]

\section{Additional File 3}

Table 3. Amount of protein ( $\mathrm{IgG})$ bound to A/G bead ( $\mu \mathrm{g} / 1 \mu \mathrm{l})$ from different sera used in this study

Click here for file

[http://www.biomedcentral.com/content/supplementary/14726750-5-22-S3.pdf]

\section{Acknowledgements}

We would like to thank Nicholas Madian for technical help and Kathryn Ching for numerous helpful suggestions and assistance. We are also grateful to Dr. R. Parniak and Dr. A. Uren for helpful comments on the manuscript. We also thank the Friends You can Count On Foundation for funding our initial work of tumor antigens. This study was funded through a grant from the Susan G. Komen Breast Cancer Foundation (BCTR02-I0I7) awarded to PDB and in part by American Cancer Society Grant CRTG-02-245-0ICCE awarded to RG. Additional support was in part by the Lombardi Comprehensive Cancer Center Tissue Culture and Biomarkers Shared Resources, U.S. Public Health Service Grant 2P30-CA-5I008 and ISI0 RRI5768-0I.

Supported in part by grant MOI RR-020359 from the National Center for Resereach Resources, National Institues of Health

\section{References}

I. Old LJ, Chen YT: New paths in human cancer serology. J Exp Med 1998, I87: I |63-1 I67.

2. Preuss KD, Zwick C, Bormann C, Neumann F, Pfreundschuh M: Analysis of the $B$-cell repertoire against antigens expressed by human neoplasms. Immunol Rev 2002, I 88:43-50.

3. Wadhwa M, Skog AL, Bird C, Ragnhammar P, Lilljefors M, Gaines-Das $R$, Mellstedt $H$, Thorpe R: Immunogenicity of granulocyte-macrophage colony-stimulating factor (GM-CSF) products in patients undergoing combination therapy with GM-CSF. Clin Cancer Res 1999, 5:1353-1361.

4. Burbelo PD, Kisailus AE, Peck JW: Detecting protein-protein interactions using Renilla luciferase fusion proteins. Biotechniques 2002, 33: 1044-1048. 1050.

5. Vogelstein B, Kinzler KW: Cancer genes and the pathways they control. Nat Med 2004, 10:789-799.

6. Bardelli A, Parsons DW, Silliman N, Ptak J, Szabo S, Saha S, Markowitz S, Willson JK, Parmigiani G, Kinzler KW, Vogelstein B, Velculescu VE: Mutational analysis of the tyrosine kinome in colorectal cancers. Science 2003, 300:949.

7. Wang Z, Shen D, Parsons DW, Bardelli A, Sager J, Szabo S, Ptak J, Silliman N, Peters BA, van der Heijden MS, Parmigiani G, Yan H, Wang TL, Riggins G, Powell SM, Willson JKV, Markowitz S, Kinzler KW, Vogelstein B, Velculescu VE: Mutational analysis of the tyrosine phosphatome in colorectal cancers. Science 2004, 304: I 164-I I66.

8. Wang Z, Cummins JM, Shen D, Cahill DP, Jallepalli PV, Wang TL, Parsons DW, Traverso G, Awad M, Silliman N, Ptak J, Szabo S, Willson JKV, Markowitz S, Goldberg ML, Karess R, Kinzler KW, Vogelstein B, Velculescu VE, Langauer C: Three classes of genes mutated in colorectal cancers with chromosomal instability. Cancer Res 2004, 64:2998-300I.

9. Rajagopalan H, Jallepalli PV, Rago C, Velculescu VE, Kinzler KW, Vogelstein B, Lengauer C: Inactivation of hCDC4 can cause chromosomal instability. Nature 2004, 428:77-8I. 
10. Samuels $Y$, Wang Z, Bardelli A, Silliman N, Ptak J, Szabo S, Yan H, Gazdar A, Powell SM, Riggins GJ, Willson JKV, Markowitz S, Kinzler $K W$, Vogelstein B, Velculescu VE: High frequency of mutations of the PIK3CA gene in human cancers. Science 2004, 304:554.

II. Perou CM, Sorlie T, Eisen MB, van de Rijn M, Jeffrey SS, Rees CA, Pollack JR, Ross DT, Johnsen H, Akslen LA, Fluge O, Pergamenschikov A, Williams CL, Xhu SX, Lonning PE, Borresen-Dale AL, Brown PO, Botstein D: Molecular portraits of human breast tumours. Nature 2000, 406:747-752.

12. van't Veer LJ, Dai $H$, van de Vijver MJ, He YD, Hart AA, Mao M, Peterse HL, van der Kooy K, Marton MJ, Witteveen AT, Schreiber G], Kerkhoven RM, Roberts C, Lisley PS, Bernards R, Friend SH: Gene expression profiling predicts clinical outcome of breast cancer. Nature 2002, 4I 5:530-536.

13. Sorlie T, Perou CM, Tibshirani R, Aas T, Geisler S, Johnsen H, Hastie $T$, Eisen MB, van de Rijn M, Jeffrey SS, Thorsen T, Quist H, Matese JC, Brown PO, Botstein D, Lonning PE, Borresen-Dale AL: Gene expression patterns of breast carcinomas distinguish tumor subclasses with clinical implications. Proc Natl Acad Sci U S A 200I, 98:10869-10874.

14. Sorlie T, Tibshirani R, Parker J, Hastie T, Marron JS, Nobel A, Deng S, Johnsen H, Pesich R, Geisler S, Demeter J, Perou CM, Lonning PE, Brown PO, Borresen-Dale AL, Botstein D: Repeated observation of breast tumor subtypes in independent gene expression data sets. Proc Natl Acad Sci U S A 2003, 100:8418-8423.

15. Sotiriou C, Neo SY, McShane LM, Korn EL, Long PM, Jazaeri A, Martiat P, Fox SB, Harris AL, Liu ET: Breast cancer classification and prognosis based on gene expression profiles from a population-based study. Proc Natl Acad Sci U S A 2003, I00:10393-10398.

16. Takahashi M, Chen W, Byrd DR, Disis ML, Huseby ES, Qin H, McCahill L, Nelson H, Shimada H, Okuno K: Antibody to ras proteins in patients with colon cancer. Clin Cancer Res 1995, I: I07I- 1077.

17. Soussi T: $\mathbf{p} 53$ Antibodies in the sera of patients with various types of cancer: a review. Cancer Res 2000, 60:1777-1788.

18. Lubin R, Schlichtholz B, Bengoufa D, Zalcman G, Tredaniel J, Hirsch A, de Fromentel CC, Preudhomme C, Fenaux P, Fournier G.: Analysis of $\mathrm{p} 53$ antibodies in patients with various cancers define B-cell epitopes of human p53: distribution on primary structure and exposure on protein surface. Cancer Res 1993, 53:5872-5876

19. Vennegoor CJ, Nijman HW, Drijfhout JW, Vernie L, Verstraeten RA, von Mensdorff-Pouilly S, Hilgers ], Verheijen RH, Kast WM, Melief C], Kenemans P: Autoantibodies to $\mathrm{p} 53$ in ovarian cancer patients and healthy women: a comparison between whole p53 protein and 18-mer peptides for screening purposes. Cancer Lett 1997, I 16:93-101.

20. Ishikawa T, Fujita T, Suzuki Y, Okabe S, Yuasa Y, Iwai T, Kawakami Y: Tumor-specific immunological recognition of frameshiftmutated peptides in colon cancer with microsatellite instability. Cancer Res 2003, 63:5564-5572.

21. Fensterle J, Becker JC, Potapenko T, Heimbach V, Vetter CS, Brocker $E B$, Rapp UR: B-Raf specific antibody responses in melanoma patients. BMC Cancer 2004, 4:62.

22. Stockert E, Jager E, Chen YT, Scanlan MJ, Gout I, Karbach J, Arand M, Knuth A, Old LJ: A survey of the humoral immune response of cancer patients to a panel of human tumor antigens. J Exp Med 1998, 187:1349-1354.

23. Zhang JY, Casiano CA, Peng XX, Koziol JA, Chan EK, Tan EM: Enhancement of antibody detection in cancer using panel of recombinant tumor-associated antigens. Cancer Epidemiol Biomarkers Prev 2003, I 2:136-| 43.

24. Bjorck L, Kronvall G: Purification and some properties of streptococcal protein $\mathbf{G}$, a novel IgG-binding reagent. I Immunol 1984, I 33:969-974.

25. Utz PJ, Gensler TJ, Anderson P: Death, autoantigen modifications, and tolerance. Arthritis Res 2000, 2:10I-II4.

26. Schellekens GA, de Jong $B A$, van den Hoogen $F H$, van de Putte $L B$, van Venrooij WJ: Citrulline is an essential constituent of antigenic determinants recognized by rheumatoid arthritis-specific autoantibodies. J Clin Invest 1998, 10 I:273-28I.

27. Yamada R, Suzuki A, Chang X, Yamamoto K: Citrullinated proteins in rheumatoid arthritis. Front Biosci 2005, 10:54-64.

28. Koenen M, Ruther U, Muller-Hill B: Immunoenzymatic detection of expressed gene fragments cloned in the lac $Z$ gene of $E$. coli. Embo J 1982, 1:509-5 |2.
29. Ruther $U$, Koenen M, Sippel AE, Muller-Hill B: Exon cloning: immunoenzymatic identification of exons of the chicken lysozyme gene. Proc Natl Acad Sci U S A 1982, 79:6852-6855.

30. Phizicky EM, Fields S: Protein-protein interactions: methods for detection and analysis. Microbiol Rev 1995, 59:94-123.

31. Bode AM, Dong Z: Post-translational modification of p53 in tumorigenesis. Nat Rev Cancer 2004, 4:793-805.

32. Lim YP: Mining the tumor phosphoproteome for cancer markers. Clin Cancer Res 2005, II:3163-3169.

33. Hammel P, Boissier B, Chaumette MT, Piedbois P, Rotman N, Kouyoumdjian JC, Lubin R, Delchier JC, Soussi T: Detection and monitoring of serum p53 antibodies in patients with colorectal cancer. Gut 1997, 40:356-361.

34. Crawford LV, Pim DC, Bulbrook RD: Detection of antibodies against the cellular protein $\mathrm{p} 53$ in sera from patients with breast cancer. Int J Cancer 1982, 30:403-408.

35. Pirone DM, Fukuhara S, Gutkind JS, Burbelo PD: SPECs, small binding proteins for Cdc42. J Biol Chem 2000, 275:22650-22656.
Publish with Biomed Central and every scientist can read your work free of charge

"BioMed Central will be the most significant development for disseminating the results of biomedical research in our lifetime. "

Sir Paul Nurse, Cancer Research UK

Your research papers will be:

- available free of charge to the entire biomedical community

- peer reviewed and published immediately upon acceptance

- cited in PubMed and archived on PubMed Central

- yours - you keep the copyright 